\title{
THE DEVELOPMENT OF A ROBUST RISK MANAGEMENT PLAN FOR THE CONTINUOUS SUPPLY OF WATER TO HOSPITALS IN THE WESTERN CAPE PROVINCE
}

\author{
A. Dippenaar ${ }^{1 \#}$ \& S.T. Bezuidenhout ${ }^{1 * \dagger}$
}

\section{ARTICLE INFO}

\section{Article details}

Submitted by authors 15 Jan 2019 Accepted for publication 30 Jul 2019 Available online $\quad 30$ Aug 2019

\section{Contact details}

* Corresponding author saija.bezuidenhout@up.ac.za

Author affiliations

1 Department of Industrial and Systems Engineering, University of Pretoria, South Africa

\# The author was enrolled for a BEng (Industrial Engineering) degree in the Department of Industrial and Systems Engineering, University of Pretoria, South Africa

The author was enrolled for a PhD (Industrial Engineering) degree in the Department of Industrial and Systems Engineering, University of Pretoria, South Africa

DOI

http://dx.doi.org/10.7166/30-2-2118
The objective of this research is to develop a robust water supply risk management and response plan for Somerset Hospital that reflects the institution's specific requirements, and to prepare general guidelines for the Western Cape Government Health Department in order to assist in developing risk management and response plans for all of its health care facilities. This will enable the Western Cape Government Health Department to be resilient in withstanding gradual systemic shocks and major crises in the supply of water to hospitals. The methodology is based on ISO 31000:2009, but it extends the approach using historical evaluations and a business impact analysis. Through the research it has become evident that one public sector in South Africa still lacks proper risk management planning, and that, on the whole, there is a global void in research into water resilience, especially that focusing on health care facilities.

\section{OPSOMMING}

Die doel van hierdie navorsing is om 'n robuuste watervoorsiening risikobestuur en reaksieplan vir Somerset Hospitaal te ontwikkel wat die instelling se spesifieke behoeftes aanspreek. Die navorsing gee ook algemene riglyne om die Wes-Kaap se Departement van Gesondheid te adviseer met die ontwikkeling van planne vir gesondheidsorginstellings. Dit sal die Wes-Kaap se Departement van Gesondheid in staat stel om geleidelike sistemiese skokke en die vernaamste krisisse ten opsigte van water voorsiening aan hospitale te weerstaan. Die metodiek is gebaseer op ISO31000:2009, en brei die benadering uit met historiese evaluasie en besigheid impakanalise. Die navorsing toon dat die publieke sektor in Suid-Afrika tekort skiet in risikobestuurbeplanning en 'n internasionale gaping bestaan in navorsing oor waterweerbaarheid met die fokus op gesondheidsorgfasiliteite.

\section{INTRODUCTION}

\subsection{Introduction and background}

The Western Cape Government Health Department (WCGH) is one of thirteen provincial government departments forming the Western Cape Provincial Government in South Africa. The primary responsibility and function of WCGH is to deliver an extensive range of health services to citizens of the province. These services are delivered by a variety of institutions, including three tertiary and 25 district hospitals and 226 clinics located throughout the province [1]. Somerset Hospital, the primary focus organisation of this research, is located in Greenpoint, Cape Town, and currently has 334 patient beds.

The objective of this research project is to ensure WCGH's ability to continue to deliver basic health services with the minimum of interruptions during a water supply emergency. Currently WCGH is probably not resilient enough to withstand gradual systemic shocks or major crises in the supply of 
water to health care facilities. This could have an impact on the continuous supply of water to hospitals, inevitably impacting the lives and health of patients.

This research aims to:

1. develop a robust water supply risk management and response plan for Somerset Hospital

2. develop guidelines to assist WCGH to develop risk management and response plans for its other health care facilities in building and maintaining water resilience.

\subsection{Rationale and contribution}

Hospitals require a minimum quantity and suitable quality of water supply to deliver their essential services, of which patient care is the most important. A continuous water supply can be interrupted by a variety of incidents that can either be anticipated long before they occur, such as drought, or that occur suddenly and without warning, such as a burst pipe. To ensure continuous service delivery at hospitals, an emergency water supply plan is essential. A hospital should be empowered to respond to and recover from a water supply interruption without sacrificing its essential services.

In 2018 the Western Cape Province and the City of Cape Town experienced their worst drought in 100 years. The term 'Day Zero' was used to describe the 'doomsday' when the taps would run completely dry. Although the extreme drought of 2018 in the Western Cape passed and the levels of supply dams began again to rise, the possibility of another major water crisis continues to loom large. This is due not only to a lack of rainfall, but also to the exponential growth in the Western Cape's population. According to the Socio-Economic Profile Report of 2017 [2], the population of Cape Town is expected to increase rapidly from 4055580 people in 2018 to 4232276 people in 2023 - an annual population growth rate of one per cent. At the Water Institute of Southern Africa conference in 2018, the provincial government announced that residents needed to accept that the days of a secure water supply might be over, and that water restrictions and limited access had become the 'new normal'. Climate models predict that the area will become hotter and drier as a result of the changing climate [3]. In November 2018, Japan's weather bureau confirmed the formation of El Nino in the Pacific Ocean [4], indicating the very high probability of an extreme weather system, with minimal rain and extreme heat affecting the Southern Hemisphere again in the summer of 2018-2019 [5].

In light of the recent drought, it became clear that the existing water risk management plan of the WCGH needed to be evaluated. It was concluded that the water risk management plan, although developed quite recently, was part of an overall water risk management plan for all health care facilities, and not one for individual institutions that reflected their specific requirements. In order to ensure a robust water risk management approach, it has been recommended that a risk management plan is developed for each facility [6]. It was also found that the current plan was limited in nature, focusing solely on the drought, and ignoring all other incidents that would potentially impact the supply of water. Furthermore, the current plan was found to be too generic, lacking detailed information such as an incident-specific response plan and schematic drawings of the water pipeline systems of the facilities. After the existing water risk management plan had been evaluated, it was decided that a new risk management plan should be developed that took the existing water risk management plan into consideration as its basis.

WCGH is in the process of implementing water security initiatives at most of its health care facilities; and the risk management plan approach developed for the Somerset Hospital would then be adapted and applied to other government hospitals in the province, thus meeting a broader demand.

Lastly, from the academic point of view, the available authoritative research that focuses on the topics of organisational resilience in water management and the risk management of a continuous supply of water to hospitals is very limited, being restricted to only a few previous studies that have been discussed in this paper. Therefore, this research has the potential to explore and develop a better understanding of proper water resilience and of its impact on health care facilities.

\subsection{Approach}

The approach is based on a combination and adaptation of the approaches of the Center for Disease Control and Prevention in the United States and the American Water Works Association, together with the prevention, preparedness, response, and recovery (PPRR) model - all following the ISO 31000:2009 standard. 
The rest of the article is organised as follows: Section 2 discusses the applicable literature, and Section 3 describes the methodology in more detail. The results and the validation are discussed in Section 4 before the document is concluded in Section 5 .

\section{LITERATURE REVIEW}

Numerous researchers have investigated the concepts of risk management and resilience. Of these two topics, risk management has the most mature literature base, covering the principles, mechanisms, guidelines, and practical protocols of risk identification and assessment, and also reflecting some applications in the health care industry $[7,8,9,10,11,12,13]$. On the other hand, according to Bhamra, Dani and Burnard, K. [14] the term 'resilience' is typically approached in a broader way: the context and the field of the term may change, but the concept is always closely related to the capability to withstand and recover from challenges [14]. The perspectives of organisational and systems resilience provide the most suitable context for this study, in which the planning and management of organisational responses is discussed [14, 15,16, 17]. Within these two themes and their sub-areas, however, no significant organisational water risk management-specific sources are available. The main water-related research focuses on the water security paradigm mostly policy from a socio-ecological point of view $[18,19,20]$. Reflecting this, Cook and Bakker [18] found that water security and related terms appeared in only 45 papers in 2010 and that, of these, the majority discussed state-level issues and protection against water-related environmental hazards.

\subsection{Risk management in government entities}

In their study of South Africa's risk maturity, Coetzee and Lubbe [21] found that most of the private sector in South Africa can be classified as 'risk mature', while the public sector still lacks many elements in its specific risk management plans. Each public sector institution can develop its own risk management plan, as long as it is based on the principles set by the National Treasury's Risk Management Framework [22]. The risk management plan suggested by the National Treasury is based on the methods set in ISO 31000:2008 and the King Code of Governance of South Africa, and executed in five phases [22]:

1. Risk identification;

2. Risk assessment evaluation;

3. Risk response;

4. Reporting and communication; and

5. Risk monitoring

\subsection{Risk management in hospitals}

Brown [6] notes that, within an organisation as diverse, dynamic, and complicated as a hospital, new plans and programmes are constantly considered and introduced. He defines 'risk management' within an organisation such as a hospital as the prevention of loss or liability control, and states that the purpose of risk management is to eliminate any problems that might cause harm to the hospital organisation, its staff, and most vitally, its patients - the public [6].

Brown [6] suggests that, when developing risk management plans for hospitals, it is important to consider the specific needs of each hospital. The development of a risk management programme does not necessarily need to start from a scratch; but it might require a change in emphasis, an improved coordination of activities that already exist, and reorganising current practice. Thus it is suggested that, when starting to develop a risk management plan, the focus should be on the inventory of already existing activities. Merely defining the prerequisites for effective risk management is already a healthy organisational exercise. This will assist the hospital to identify quickly many of the current weaknesses and hospital needs that should be addressed while it is still in the process of formalising its risk management process [6].

The establishment and development of a risk management plan for a hospital can be accomplished in many ways. Brown [6] suggests that the following should always be taken into consideration:

- The developed risk management plan should be coordinated with existing organisational activities; 
- $\quad$ Risk management can be seen as a staff function, and its main purpose is to support and advise other operational activities within the organization;

- The developed risk management plan should try to cover all departments in the hospital;

- In order to ensure the success of the developed risk management plan, there should be adequate support and commitment from management, manpower, materials, methods, and money.

The key for hospitals is to have the risk management structure in place, and that the risk management plan is developed for each hospital individually, since every hospital will have different needs and requirements. It is also important to categorise the identified risks together with the suggested risk management plan [6].

\subsection{Organisational resilience in water management}

In order for an organisation to be water-resilient, it requires a resilient management of processes, infrastructure, and behaviour [23]. To ensure resilience in all departments that require it, risk management plans should also be developed and implemented. These themes are illustrated in Figure 1 below.

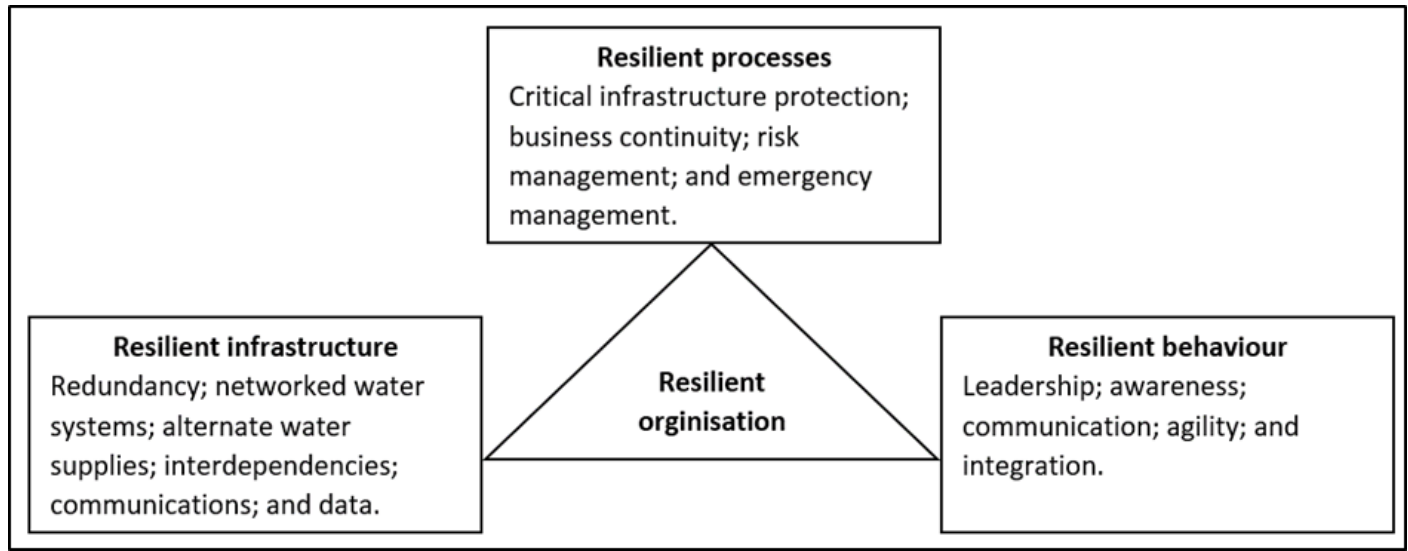

Figure 1: The three themes of organisational resilience [23].

ISO 22301:2012 emphasises the role of business continuity planning in helping an organisation to become more resilient [24]. The State Government of Queensland in Australia found that the most comprehensive approach to business continuity planning is the prevention, preparedness, response, and recovery (PPRR) model. Each step in the model involves different actions [25]:

1. Prevention: to take action to reduce the likelihood and/or effects of an incident occurring therefore preparing a risk management plan.

2. Preparedness: to implement controls before an incident occurs to ensure that the organisation can effectively respond and recover - therefore conducting a business impact analysis.

3. Response: to control, contain, or minimise the impacts that an incident may have caused therefore developing an incident response plan.

4. Recovery: to take action to minimise disruption caused by an incident and the recovery time thereafter - therefore developing a recovery plan.

\subsection{Risk management of continuous water supply to hospitals}

The risk management of a continuous water supply to hospitals addresses various aspects. The current WCGH water continuity plan, the general water quality requirements, the general methods to minimise water usage in hospitals, and similar projects were researched and analysed.

The current water continuity plan of the WCGH is not set up for each hospital individually, but is designed to be generally applicable in all the hospitals in the province. WCGH has formed a Departmental Water Supply Response Team that is responsible for conducting a situational analysis, identifying critical needs, and developing a continuity plan for the department's operations to investigate the following [26]: 
- $\quad$ Reduction of water consumption in order to save, as far as possible, scarce water resources;

- The preparedness of hospitals for the possibility of water rationing; and

- $\quad$ Preparedness for the total loss of a municipal water supply.

The team developed and suggested responses to the three levels of action that would be taken as the availability of water is reduced [26]:

Level one - severe pressure reduction. This action, causing a poor flow of water, may have an impact on some of the medical equipment that is used in hospitals, and raises the possibility of poor quality water and the inability of health care facilities to keep gravity feed tanks full. The suggested solution was to consider cancelling any elective surgical procedures in order to assist the health care facility in water conservation.

Level two - the possibility of the introduction of water shedding, meaning that the water supply would not be continuous and could be switched on and off in certain areas according to a specified schedule. The suggested solution would be facility-specific, depending on the amount of water storage at each health care facility. The solution included ceasing all showers and baths unless the water storage is more than 75 per cent full, to cancel all elective surgical procedures (as in the response to level one action), and to only have severely soiled laundry replaced and sent for cleaning.

Level three - all municipal water supplies through pipelines are switched off, and water can only be obtained from tankers. The solution, as in the level two actions, will be more facilityspecific. Facilities that have access to alternative and additional water by means of a borehole will continue to provide health care services, but only limited services, as the capacity to provide such services depends solely on the quality and amount of water available at the health care facility. Facilities that do not have an additional water supply will need to move patients to another facility that can provide drinking water and sanitation services from water tankers. Such facilities will only be able to deliver the absolute basics of heath care to their patients.

In cases where no water can be provided to a health care facility, that facility will have to be closed [26].

It was noted by the team that it is of vital importance for WCGH to work alongside the private hospital sector and the South African military health services during a water crisis because, in the event that any hospital is unable to function at full capacity, it will have an impact on the whole health care facility platform in the province [26].

In a study by Yiannou [20] for WCGH on water conservation and recycling in healthcare facilities, it was found that domestic water is used in hospitals for the following purposes:

- $\quad$ Potable water consumption;

- Washing, sterilisation, and cleaning throughout the whole facility;

- $\quad$ Ablution facilities for patients and staff (including scrub-up for medical personnel); and

- Heating, cooling, and ventilation (i.e., hot water for space heating and chilled water for cooling).

The typical daily water demand in district, regional, and provincial hospitals (the category under which the Somerset Hospital falls) is $300-450$ litres/bed/day. For the water to be used for certain aspects of health care, it also has to meet certain quality standards [20].

Every health care facility disposes of water after use. This water is better known as 'wastewater', which can be further categorised as follows [20]:

- Hazardous wastewater: This water typically includes infectious, chemical, pathological, radioactive, and pharmaceutical waste. The typical sources of hazardous waste include inpatient ablutions and toilets, radiology, and sluice rooms. The constituents of hazardous waste water include urine, blood, vomit, multi-resistant bacteria, viruses, and antibiotics. All hazardous wastewater that is generated by a healthcare facility is defined and disposed of as stipulated by South African National Standard SANS 10248. 
- Black wastewater: This water is typically produced by kitchen sinks and the flushing of outpatient toilets. The constituents of black wastewater include urine, organic waste, and faecal matter.

- Grey wastewater: This category of wastewater is produced through the use of baths, showers, basins, and laundry, all containing large amounts of soap, oils, fats, and skin cells. This category of wastewater does not include any harsh chemical cleaning products such as drain cleaners.

Yiannou [20] proposed a variety of water conservation methods, and highlighted that, when considering and evaluating the different methods of water conservation, the risk to public health should be considered. The three main methods of water conservation are illustrated and explained in Figure 2.

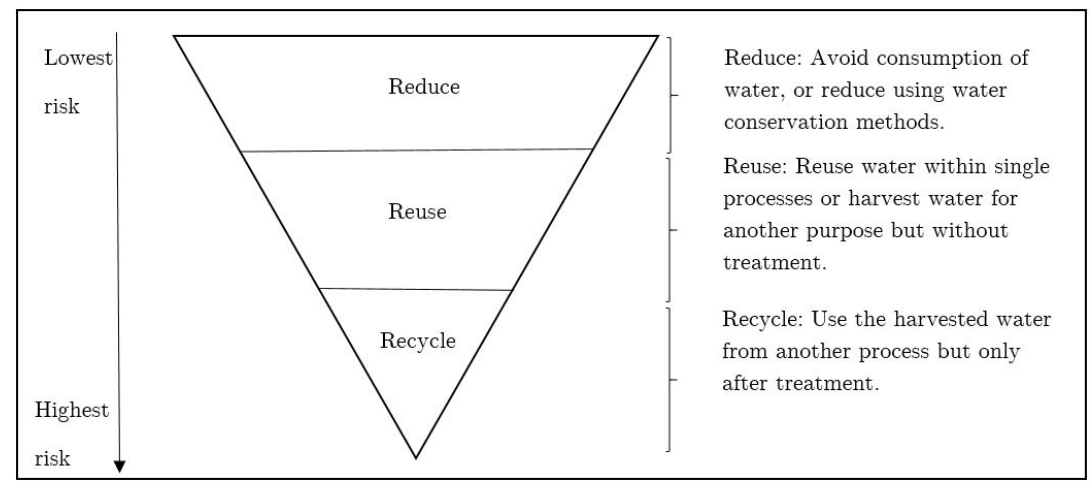

Figure 2: The main methods of water conservation [20].

It was also noted that, if the reusing and recycling methods are considered or chosen, sources that tend to provide relatively 'clean' water should be harnessed first. The more polluted the water, the more it has to be treated - and the more expensive it will be. Therefore it is suggested that the recycling of water should only be considered once water usage has been reduced and reused, and there is still a need for more water [20].

Sources of water that can typically be reduced directly without prior treatment and with a low chance of human ingestion include: rain water, clean process water, fire service testing water, and storm water. Sources of water that has to be treated before it can be used include grey water and sewage [20].

Water that is used within a healthcare facility has to meet the minimum standard, depending on what the water is used for. Yiannou [20] compiled a report on these standards for WCHG:

- $\quad$ SANS 10252 Part 1 - Water Supply Installations for Buildings;

- $\quad$ SANS 10252 Part 2 - Drainage Installations for Buildings;

- $\quad$ SANS 241 Parts 1 and 2 - Drainage Installations for Buildings;

- $\quad$ SANS 10248 - Management of healthcare waste;

- $\quad$ Small waste and small treatment works (Department of Public Works Design Guidelines); and

- $\quad$ IUSS Health Facility Guides: Building engineering facilities.

In any plans developed for water within a health care facility, it should be very clear what the end use of the water will be because, according to these requirements, for certain uses a certain class of water (Class 0 , Class 1 , or Class 2 ) is required. The possible end usages of water and the quality class of water required is illustrated in Table 1 [20].

In the United States, the Center for Disease Control and Prevention, in partnership with the American Water Works Association, developed an overall water supply risk management plan guide after several water supply interruption incidents occurred across the nation, resulting in certain health care operations having to be stopped [27]: 
- A health care facility in Florida lost all water services for five hours as a result of a water main breaking nearby;

- A health care facility in Nevada lost all water services for twelve hours due to a break in the hospital's main water supply line;

- A hospital in West Virginia lost all water services for thirty hours due to a water main breaking nearby; and

- A hospital in Texas lost all water services for forty-eight hours as a result of an ice storm that caused a power outage, thus cutting power to the water treatment plant.

Table 1: Hospital functions and the quality classes of water needed [20].

\begin{tabular}{|c|c|}
\hline Use & Water quality required \\
\hline $\begin{array}{c}\text { Drinking, laboratory, CSSD, mechanical plant } \\
\text { heating and cooling (high recycling) }\end{array}$ & Class 0 \\
\hline $\begin{array}{c}\text { Mechanical plant heating and cooling (once } \\
\text { through), baths, showers, basins, laundry }\end{array}$ & Class 1 \\
\hline Evisceration tables & $\begin{array}{c}\text { Class 1 (Class 2 can also be acceptable if the water is not } \\
\text { used for forensic purposes) }\end{array}$ \\
\hline Kitchen & $\begin{array}{c}\text { Class 1 or Class 2 (Class 1 is needed for food preparation, } \\
\text { whereas Class 2 can be used for washing the floors) }\end{array}$ \\
\hline $\begin{array}{c}\text { Sluice rooms, autopsy rooms, decontamination } \\
\text { areas, ablution, car wash bays, irrigation }\end{array}$ & $\begin{array}{c}\text { Class 2 (this is only acceptable if the storage of the fire } \\
\text { fighting water is separate from domestic supplies) }\end{array}$ \\
\hline Fire fighting & Clations \\
\hline
\end{tabular}

During the development of the plan, a suggested method to be used had four phases [27]:

Phase 1: Assemble health care facility's emergency water supply team and all the necessary background documents. This phase involves identifying all appropriate staff members who will be needed for the facility's emergency water supply team. It will be the responsibility of these team members to develop the emergency water supply plan. It is suggested that, in order to ensure the development of a robust and comprehensive plan, expertise from all relevant individuals should be taken into account and used. Team members to be selected for the development of the emergency water supply plan should include employees from various departments within the health care facility, including facilities management; environment compliance, safety, and health; administration; management; nursing; infection prevention and control; medical services; risk management; security; and emergency preparedness.

Phase 2: Investigating and understanding the water usage of the health care facility through carrying out a water audit. This will assist in determining the minimum amount of water that is required by a health care facility.

\section{Phase 3: Analyse the alternatives to water supply in an emergency.}

Phase 4: Develop and exercise the emergency water supply plan risk management (similar to ISO 31000:2009). Based on phases one to three, develop and document an applicable emergency water supply plan for the health care facility.

To conclude, when developing a risk management plan for the continuous supply of water to hospitals, it is important to consider the initiatives already carried out, the amount of water needed and what it is used for, the quality of water required, and the people who will be involved in the development process. It is also important to treat the plan as a 'living document' that needs constant revising and development in order to stay relevant [27].

\section{METHODOLOGY}

For the development of a water risk management and response plan for Somerset Hospital, a combination of the US Center for Disease Control and Prevention and the American Water Works 
Association approach (steps 1-4), together with the PPRR model (steps 5-6), the following adaptation was implemented:

Step 1: Form and assemble a water risk management team, and gather all necessary background information;

Step 2: Understand the water usage and requirements of the facility;

Step 3: Analyse the current water risk management plan;

Step 4: Develop a water risk management plan according to ISO 31000:2009;

Step 5: Conduct a business impact analysis;

Step 6: Develop an incident response plan.

First, as Step 1, appropriate staff members were identified to form the water risk management team by determining those who might have an impact on the supply and usage of water, and who would be needed to respond to incidents when they occur.

In Step 2 the background information of the facility was assembled by reviewing the existing engineering drawings of the water pipeline, reviewing the current water risk management plan, completing a physical site inspection, and analysing the water usage data. The usage data included the amount of water that Somerset Hospital uses and the percentile water consumption of the various departments of the hospital. This data was used to determine the minimum amount of water the health care facility uses and thus requires each day under normal operating conditions.

The water usage was measured each day by documenting the water meter reading to determine the water usage under normal operating conditions. This data was analysed and an average daily water usage was calculated. From the data it was found that Somerset Hospital currently uses 5,306,000 litres of water each month - that is, 177,000 litres a day.

As the hospital currently has none of the equipment required to measure the water usage of each separate department, an estimate of the departmental water usage was calculated following the Environmental Protection Agency calculation guidelines [28]. This produced the following division of consumption: 35 per cent restrooms/domestic; 20 per cent heating and cooling; 15 per cent medical equipment; nine per cent laundry; seven per cent kitchen; seven per cent landscaping; and seven per cent other.

In Step 3 the existing water risk management plan was reviewed. From the analysis it was found that the plan was developed as a part of the overall water risk management plan for all the health care facilities, and was not developed specifically for Somerset Hospital. The plan focused solely on the drought, and suggested only two solutions to be implemented - reducing water consumption and preparing for total water loss. The current water risk management plan was found to be general and lacking in detailed information - for example, an incident-specific recovery plan and schematic drawings of the water pipeline system. After the analysis was completed it was decided that a new water risk management plan should be developed, with the existing water risk management plan as its basis.

In Step 4, in order to build a robust risk management plan, the risk management method of ISO 31000:2009, divided into a further seven phases, was applied:

Establish and define the context: For the completion of this phase, the objectives were set, all of the internal and external parameters were defined, and the risk criteria and scope of the process were defined (see previous steps).

Risk identification: Semi-structured interviews were conducted, brainstorming sessions were held, historical risks and previous incidents were reviewed, and the risk identification check lists were used to validate the risks.

A list of $\mathbf{4 7}$ questions was developed to gather as much information as possible about the hospital, to assist in the identification of risks. The questions were asked to understand better the unclear areas of the current risk management plan, to understand better the health care facility's operations, to assist directly with risk identification, to investigate and understand the historical incidents that have occurred and have had an impact on the supply of water to the hospital, to determine the current risk control parameters that have been implemented, and lastly, to gain 
insight into the future of the health care facility. The questions that were asked during the interview included, but were not limited to, these:

"Does the hospital have a plan and the needed systems to connect to alternative water sources to support the sprinkler system, cooling system, and waste water system?"

"What part of the hospital would be the most important always to have water?"

"Is there currently any water conservation implemented at the hospital?"

"Does the hospital have a set of processes to determine whether there is a need to cancel elective surgeries and procedures or other non-essential functions (for example, meetings or conferences)?"

During the multiple brainstorming sessions on the water supply at Somerset Hospital, the concept of water resilience, and some of the interview questions, were discussed in detail. This assisted the stakeholders to identify possible areas of risk and to come up with ideas of how the risks might be resolved or minimised. Throughout the course of the brainstorming sessions, notes were taken to ensure that all relevant ideas were recorded.

Analyse the risks: An understanding of all of the identified risks was developed during this stage. A risk matrix method was used to prioritise the risks with the help of a consequence chart. For the development of a risk management plan, a $5 \times 5$ matrix was developed, and each of the identified risks was first scored from one to five for the likelihood of occurring; (1) once in ten years, (2) once in five years, (3) once a year, (4) once in six months, and (5) more than once in six months Second, each risk was scored from one to five for the consequences of the risk, with each of the scored ratings having different meanings. The categories on which a risk could have impact were: people (harm to people), financial (financial impact on the facility), reputational (impact on the reputation/community), legal (legal and regulatory implications), and assets (impact on the assets of the facility). A detailed description of the consequences is given in Table 2.

Table 2: Detailed description of each consequence related to the rating score.

\begin{tabular}{|c|c|c|c|c|c|c|}
\hline \multicolumn{7}{|l|}{ Consequence } \\
\hline & & People & Financial & Reputational & Legal & Assets \\
\hline $\begin{array}{l}\text { Major/ } \\
\text { Catastrophic }\end{array}$ & 5.0 & $\begin{array}{l}\text { Multiple } \\
\text { fatalities. }\end{array}$ & $\begin{array}{l}\text { Damage } \\
\text { more than } \\
\text { R3 million. }\end{array}$ & $\begin{array}{l}\text { International } \\
\text { media } \\
\text { attention. } \\
\text { Long term } \\
\text { impact on } \\
\text { patient } \\
\text { numbers. }\end{array}$ & $\begin{array}{l}\text { Very considerable } \\
\text { penalties \& } \\
\text { prosecutions. } \\
\text { Multiple law suits \& } \\
\text { jail terms. }\end{array}$ & $\begin{array}{l}\text { Critical equipment } \\
\text { permanently } \\
\text { damaged. }\end{array}$ \\
\hline High & 4.0 & Fatality. & $\begin{array}{l}\text { Damage } \\
\text { R1,5 million } \\
\text { - R3 million. }\end{array}$ & $\begin{array}{l}\text { International } \\
\text { media } \\
\text { attention. }\end{array}$ & $\begin{array}{l}\text { Major breach of the } \\
\text { law; considerable } \\
\text { prosecution and } \\
\text { penalties. }\end{array}$ & $\begin{array}{l}\text { Critical equipment } \\
\text { damaged. }\end{array}$ \\
\hline $\begin{array}{l}\text { Medium / } \\
\text { significant }\end{array}$ & 3.0 & $\begin{array}{l}\text { Health } \\
\text { impact on } \\
\text { patients. }\end{array}$ & $\begin{array}{l}\text { Damage } \\
\text { R500 000 - } \\
\text { R1,5 } \\
\text { million. }\end{array}$ & $\begin{array}{l}\text { National } \\
\text { media } \\
\text { attention. }\end{array}$ & $\begin{array}{l}\text { Serious breach of } \\
\text { law; investigation/ } \\
\text { report to authority, } \\
\text { prosecution and/or } \\
\text { moderate penalty } \\
\text { possible. }\end{array}$ & $\begin{array}{l}\text { General equipment } \\
\text { permanently } \\
\text { damaged. }\end{array}$ \\
\hline Low & 2.0 & $\begin{array}{l}\text { Health } \\
\text { impact on } \\
\text { patients. }\end{array}$ & $\begin{array}{l}\text { Damage } \\
\text { R250 000 - } \\
\text { R500 000. }\end{array}$ & $\begin{array}{l}\text { Regional } \\
\text { public } \\
\text { concern. }\end{array}$ & $\begin{array}{l}\text { Minor legal issue; } \\
\text { noncompliance and } \\
\text { breaches of the law. }\end{array}$ & $\begin{array}{l}\text { General equipment } \\
\text { damaged. }\end{array}$ \\
\hline Minor & 1.0 & $\begin{array}{l}\text { Minimal } \\
\text { health } \\
\text { impact. }\end{array}$ & $\begin{array}{l}\text { Damage } \\
\text { R0-R250 } \\
000 .\end{array}$ & $\begin{array}{l}\text { Slight impact - } \\
\text { local public } \\
\text { awareness } \\
\text { and concern. }\end{array}$ & Low level legal issue. & $\begin{array}{l}\text { Slight impact - no } \\
\text { equipment } \\
\text { damaged. }\end{array}$ \\
\hline
\end{tabular}


Evaluate the risks: The purpose of this phase was to assist Somerset Hospital to make decisions about which of the identified risks needed to be treated, and the prioritisation of the treatment implementation based on the results of the risk analysis phase.

To determine whether a risk should be treated, the total risk score was calculated. This was done by multiplying the determined likelihood score of a risk with the associated consequence score. If the risk score was calculated to be 1-4, the risk was classified as acceptable and nothing was done to minimise the risk. If the risk score was calculated to be more than 5 , the risk was classified as unacceptable, and the risk had to be attended to in order to minimise the risk.

Resolving the risks: Resolving the risk consisted of developing a plan to deal with risks when they do occur and to manage risks before they occur, in order to minimise them and the impact they might have on the organisation. This phase involved choosing one or multiple options to modify risks, and assessing the implications of those options. To select the most viable risk treatment option from the suggested options, the total cost/financial impact, the effort to implement the treatment option, judging how long the treatment would be effective, assessing the overall impact, and any other criteria relevant to the specific risk were taken into consideration, and the best option from among the criteria was selected and implemented, as shown in Table 3.

Table 3: An example of risk treatment selection by comparing the criteria.

\begin{tabular}{|c|c|c|c|}
\hline \multicolumn{4}{|l|}{ Risk treatment options } \\
\hline $\begin{array}{l}\text { Identified risk } \\
\text { (possible events that } \\
\text { may occur) }\end{array}$ & Possible risk treatment options & Factors to consider (Selection criteria) & $\begin{array}{l}\text { Selected option (and why it } \\
\text { is selected) }\end{array}$ \\
\hline \multirow{3}{*}{$\begin{array}{l}\text { Water pipe burst - } \\
\text { before water storage } \\
\text { tanks }\end{array}$} & $\begin{array}{l}\text { Arrange for alternative water supply - for } \\
\text { example Tanker-transported water. }\end{array}$ & $\begin{array}{l}\text { *Average cost to have } 50000 \text { litres of top class water delivered costs R } 21000 \text { ( } 42 \text { cents a } \\
\text { litre). Somerset Hospital used } 177000 \text { litres of water on a daily basis. Assuming that the water } \\
\text { storage tanks were full the hospital would still require at least } 88500 \text { litres of water a day } \\
\text { (therefore R } 37170 \text { for the water). } \\
\text { *Effort is relatively low for the health care facility. } \\
\text { *Short-term solution, and will resolve the risk only while the incident is happening. } \\
\text { *The delivery of water by tank might be delayed. }\end{array}$ & \multirow{3}{*}{$\begin{array}{l}\text { Use water from the already } \\
\text { existing storage facility and } \\
\text { install digital flow meters to } \\
\text { identify leaks and bursts. } \\
\text { (Most feasible option; low } \\
\text { effort; long-term solution). }\end{array}$} \\
\hline & $\begin{array}{l}\text { Monitor the water flow within pipes with a } \\
\text { digital flow meter - when pressure drops a } \\
\text { burst can be detected. }\end{array}$ & $\begin{array}{l}\text { "Digital water flow meter cost would be R7 } 910 \text { (as calculated by Omega). } \\
\text { *After installed and set up, it has to be monitored daily - but requires minimum effort. } \\
\text { *Long-term tool that can be used to determine water pipe bursts. } \\
\text { *Will not stop water pipes from bursting, but by monitoring if the pressure drops, it can } \\
\text { indicate either a burst pipe or a leakage - therefore preventative action can also be taken to } \\
\text { prevent pipes from bursting. }\end{array}$ & \\
\hline & Use water from the existing storage facilities. & $\begin{array}{l}\text { *As the storage tanks are already implemented, no extra costs would be involved. } \\
\text { *No effort required, as the tanks are already implemented and operational. } \\
\text { "Long-term control that is already implemented. } \\
\text { *If deemed necessary, the additional water storage tank can also be restored. }\end{array}$ & \\
\hline
\end{tabular}

Review and monitor the risks: The acts of both reviewing and monitoring the risks should occur throughout the execution of the whole process and, when the process has been completed, on a periodic or ad hoc basis, as long as it is done regularly. The plan-do-check-act (PDCA) method was used to verify, improve, and monitor the risk management plan.

Communication and consultation: Effective internal and external communication and consultation are vital to ensure that all those who are accountable for the implementation of the risk management process, and all stakeholders, understand why certain actions are required, as well as the foundation on which the decisions are made. Therefore there was constant communication between the relevant stakeholders by email and telephone throughout the development of the risk management plan.

Conduct a business impact analysis: An analysis of incidents that have occurred was conducted to determine their impact on the key organisational activities. Those activities are defined as all processes that have to remain operational for a company to be able to function; and a recovery time is assigned to each key organisational activity. The business impact analysis is illustrated in Table 4.

Table 4: Business impact analysis table

\begin{tabular}{|l|l|l|l|l||}
\hline $\begin{array}{l}\text { Key } \\
\text { organisational } \\
\text { activity }\end{array}$ & Description of activity & Priority & $\begin{array}{l}\text { Impact of the activity } \\
\text { not being functional }\end{array}$ & $\begin{array}{l}\text { Recovery } \\
\text { time } \\
\text { objective }\end{array}$ \\
\hline & & & & \\
\hline & & & & \\
\hline & & & & \\
\hline & & & & \\
\hline
\end{tabular}


Develop an incident response plan: The response plan will enable the facility to respond to an incident within the least amount of time to minimise the impact of the incident (especially its impact on the key organisational activities). Therefore, the development of the response plan will help to ensure minimal disruptions to facility operations in the event of an emergency. The following elements were included in the response plan:

- $\quad$ An immediate response plan check list, using the guidelines of the Queensland Government [25];

- $\quad$ A list of the contact details of the emergency services and local authorities;

- Insurance company details;

- $\quad$ A detailed response plan for each foreseeable incident;

- $\quad$ Roles and responsibilities list (previously developed as a part of the development of the risk management plan);

- A communication plan to be used in the event of an emergency; and

- An event log to be completed as the emergency happens in order to document any incidents, the time and date of occurrence, the decisions made during the emergency, and the individual who made the decision.

\section{RESULTS}

\subsection{Somerset Hospital water risk management plan}

As an outcome of the process, an updated water risk management and response plan for Somerset Hospital was developed. An MS Excel spreadsheet formed the basis of the document, as it is accessible, easily understood, and easily adapted. An snapshot example of the response plan is presented in Figure 3.

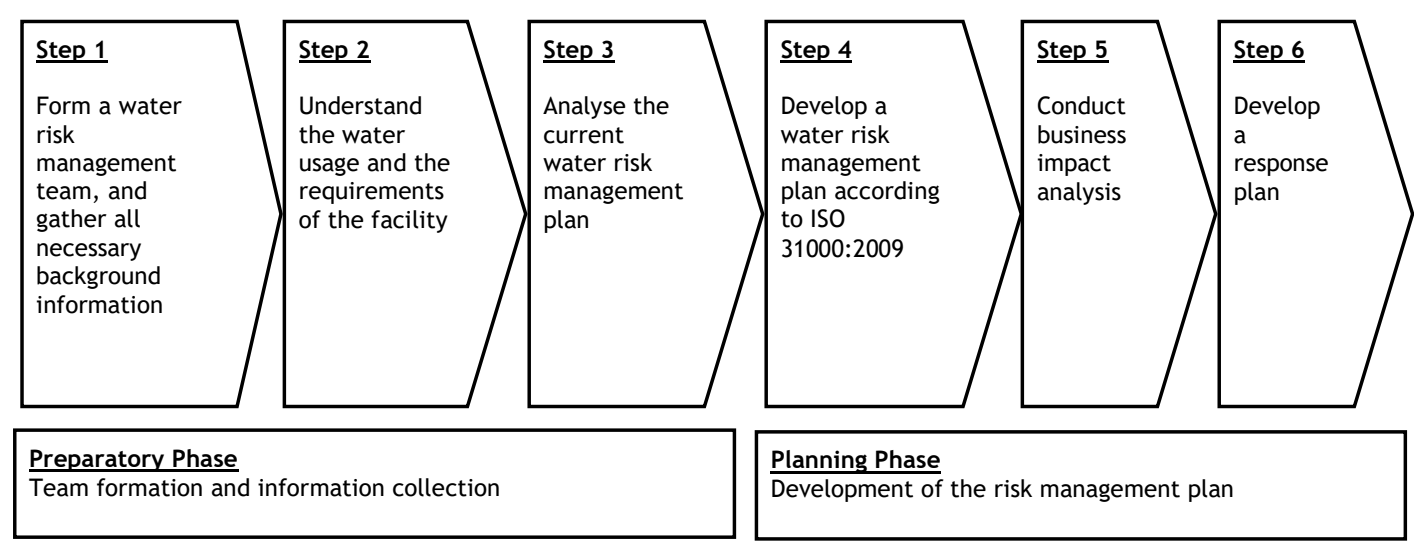

Figure 3: A snapshot of the Somerset West Hospital risk response plan.

\subsection{Guidelines for the development of a water risk management plan for WCGH}

The general guidelines to assist WCGH to develop water risk management and response plans for other health care facilities in the Western Cape Province were developed by using the Somerset Hospital water risk development methodology and updated plan as a basis. This is a novel approach, in which the ISO 31000:2009 approach is extended to include the historical evaluations (Step 2) in the preparatory phase and the business impact analysis (Step 5) in the planning phase. The overall process consists of six steps, as illustrated in Figure 4. 


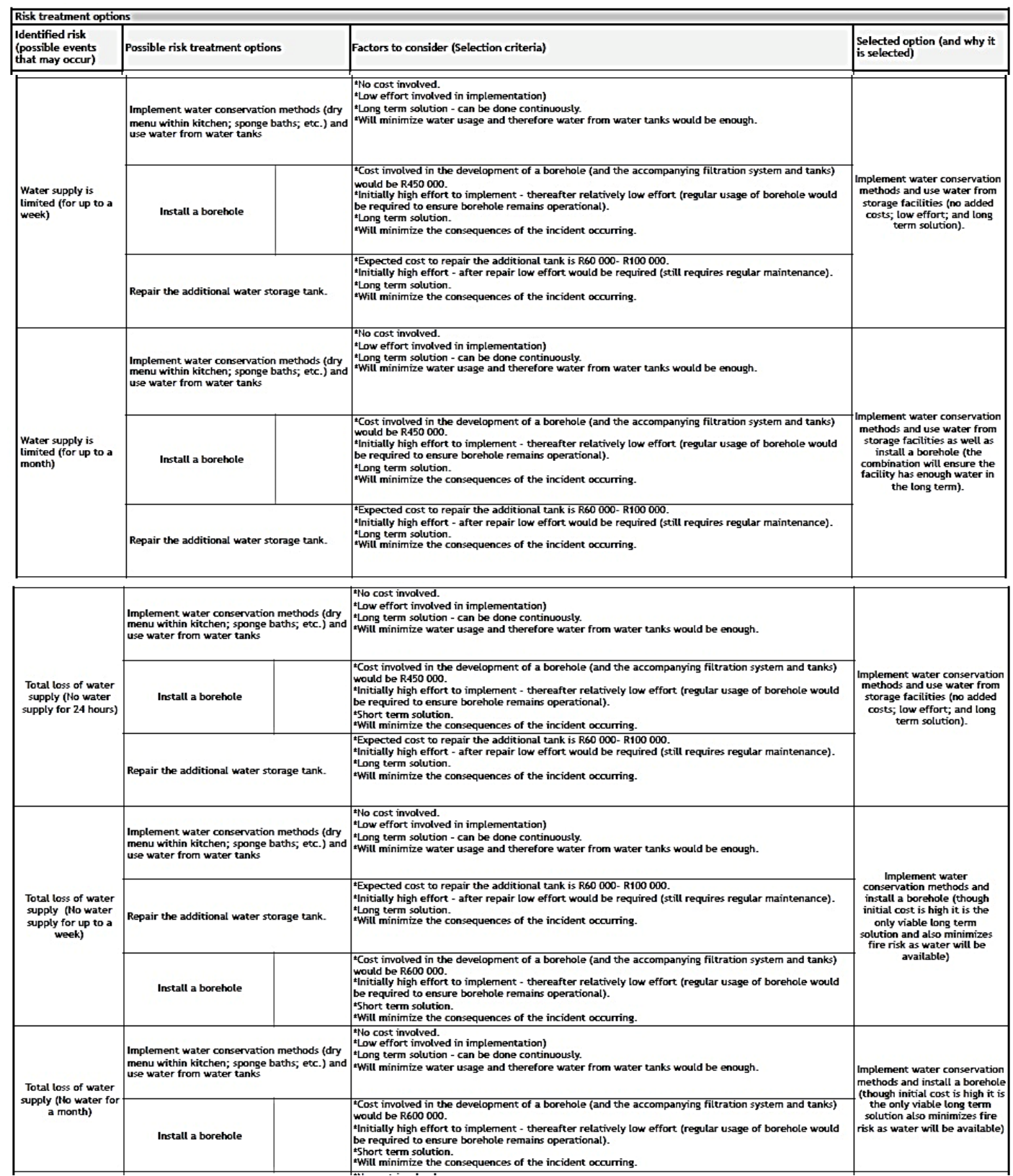

Figure 4: The process to develop a water risk management plan for a health care facility.

\subsection{Validation}

It is vitally important that the developed risk management plan is robust, reliable, comprehensive, and correct, thus meeting the objectives of the project. First, the developed risk management plan was compared with the historical risk management plans of Somerset Hospital and with two other organisations' risk management plans to ensure the high standard and comprehensiveness of the plan. To maintain confidentiality, the contents of the plans and the names of the other organisations cannot be revealed. The aspects that were compared were the following:

- The methodology used (to ensure that the correct methodology was selected and correctly executed);

- The layout and information in the document (to ensure that all the required information was documented); 
- $\quad$ Matrix used to assess the identified risks (to ensure the likelihood that scoring and consequences were developed correctly);

- $\quad$ Criteria used to select the most suitable option to treat and resolve risks (to ensure that the correct approach was followed when selecting the risk treatment options); and

- $\quad$ The guidelines for reviewing and updating the risk management plan (to ensure that the suggested schedule was acceptable).

Second, each of the techniques (brainstorming, interviews and questionnaires, reviews, checklists, consequence/likelihood matrix, cause and effect analysis, and PDCA) used to develop the risk management plan was separately evaluated to ensure the appropriateness of the intended use and the desired outputs.

Third, the developed risk management plan was compared with the check list developed by the American Water Works Association and the Center for Disease Control and Prevention in their Emergency Water Supply Planning Guide [27] to ensure the comprehensiveness and appropriateness of the plan.

The project stakeholder, WCGH, plans to use the Somerset Hospital water risk management plan as a basis for developing the water risk management plans for all the other hospitals in the province. This study will also be used as a basis for further research by the Department of Water Services and the Department of Health.

\section{CONCLUSION}

A health care facility's ability to continue to deliver health care services in a water supply emergency is crucial, as it impacts the lives and health of patients. In 2018 the Western Cape Province experienced their worst drought in 100 years, almost causing a complete shutdown of water taps throughout the province. The possibility of another major water crisis caused by climate change and fast population growth has become very real, forcing residents and organisations alike to adapt to the water restrictions and to limited access as 'a new normal'.

The recent drought in the Western Cape has made the provincial government more aware of the shortcomings of their existing emergency water supply plan and the importance of having an appropriate water risk management plan in place. After the investigation, it was found that the Western Cape Government Health Department's (WCGH) health care facilities were not waterresilient, and that the water risk management plan for the continuous supply of water to these facilities in the province needed to be revised. Furthermore, a systematic approach to maintain the water risk management plan in WCGH was needed.

The objective of this research was to develop a robust water supply risk management and response plan for Somerset Hospital that reflected the institution's specific requirements, and to prepare general guidelines for the WCGH in order to assist in developing risk management and response plans for all of its health care facilities. This will help the WCGH to be resilient in withstanding gradual systemic shocks and major crises in the supply of water to hospitals.

A minimum quantity and a suitable quality of continuous water supply is needed in a hospital environment to provide basic patient care. To ensure continuous service delivery at hospitals, an emergency water supply plan is essential. Without a supply of water that is of suitable quality, a health care centre would not be able to continue to deliver essential services to its patients, and would expose the hospital to great risk in the event of an emergency, such as in a fire break-out.

The methodological approach is based on a combination and an adaptation of the US Center for Disease Control and Prevention and the American Water Works Association's approach, together with the prevention, preparedness, response, and recovery (PPRR) model - both following the ISO 31000:2009 standard. This approach extends the ISO 31000:2009 process by emphasising the initial historically based evaluations, and adding the element of a business impact analysis to the process. Given the nature of the project, the focus has been on developing a robust methodology in order to ensure a reliable and comprehensive outcome in the form of a water risk management plan.

A revised and updated water risk management plan can be developed for a health care facility by completing this six-step process, in which the ISO 31000:2009 approach is extended to include the 
historical evaluations in the preparatory phase and the business impact analysis in the planning phase. The method applied in this study can be used as a basis for the development of a risk management plan to ensure resilience. Although this study specifically focused on ensuring water resilience in hospitals, the same method can be used to create a robust risk management plan to ensure building and maintaining resilience in other industries.

The timeframe for the development of a robust water risk management would be influenced by various factors, including but not limited to: (i) the number of sites for which the plan would be developed; (ii) the availability and accuracy of the available information (minimum water required, water usage, etc.); (iii) the willingness of employees to participate in the development of the water risk management plan; and (iv) the budget available to implement the developed plan (a limited budget that allows for only a few expenses could prolong the development and the implementation of the risk management plan). Under ideal circumstances, the timeframe to consider for the development and initial implementation would be a minimum of four months. This does not take maintaining, updating, or changing the plan into account.

Through the research it has become evident that one part of the South African public sector still lacks adequate risk management planning and that there is a general void in the research into water resilience, especially that which focuses on health care facilities. Thus the research topic itself held great potential not only for WCGH (the focus organisation) but also for the whole of the public sector - and for building the academic body of knowledge. Future research on the topic is recommended, especially if it were to focus on technical water resilience solutions in the event of a water crisis.

\section{REFERENCES}

[1] Western Cape Government. 2018. Know your government. [Online] Available at https://www.westerncape.gov.za/yourgov/[Accessed on 17th March 2018].

[2] Western Cape Government_2017. Socio-economic profile. [Online] 1, p.2. Available at: https://www.westerncape.gov.za/assets/departments/treasury/Documents/Socio-economicprofiles/2017/city-of-cape-town-2017-socio-economic-profile-sep-lg-26-january-2018.pdf [Accessed on 6th August 2018].

[3] Gosling, M. 2018. Cape Town dams filling up, but drought not broken. News24, 2018-06-25. [Online] Available at https://www.news24.com/SouthAfrica/News/cape-town-dams-filling-up-but-drought-notbroken-20180625m [Accessed on 5th November 2018].

[4] Chang-Ran, K. \& Schmollinger, C. 2018. Japan weather bureau says El Nino appears to have formed. Reuters, 2018-11-09. [Online] Available at https://www.reuters.com/article/us-japan-weatherelnino/japan-weather-bureau-says-el-nino-appears-to-have-formedidUSKCN1NEOCO?feedType=RSS\&feedName=environmentNews\&utm_source=feedburner\&utm_medium=fe ed\&utm_campaign $=$ Feed $\% 3 \mathrm{~A}+$ reuters $\% 2 \mathrm{Fenvironment}+\% 28 \mathrm{News}+\% 2 \mathrm{~F}+\mathrm{US}+\% 2 \mathrm{~F}+$ Environment $\% 29$ [Accessed on 12th November 2018].

[5] Head, T. 2018. El Nino: Prepare for a long, abnormally hot summer in South Africa. The South African, 2018-11-09. [Online] Available at https://www.thesouthafrican.com/how-el-nino-effects-weather-southafrica-summer/ [Accessed on 12th November 2018].

[6] Browns, B.L. 1979. Risk management for hospitals: A practical approach. Health Care Management Review, 4(4).

[7] Aven, T. 2016. Risk assessment and risk management: Review of recent advances on their foundation. European Journal of Operational Research, 253(1), pp. 1-13.

[8] Dionne, G. 2013. Risk management: History, definition, and critique. Risk Management and Insurance Review, 16(2), pp. 147-166.

[9] Lubka, T. 2002. Risk identification - basic stage in risk management. Environmental Management and Health, 13(3), pp. 290-297.

[10] Luko, S. 2014. Risk assessment techniques. Quality Engineering, 26(3), pp. 379-382.

[11] Moloi, T. 2016. Key mechanisms of risk management in South Africa's national government departments: The public sector risk management framework and the King III benchmark. International Public Administration Review, 14(2-3), pp. 37-52.

[12] Powell, J., Mustafee, N., Chen, A. \& Hammond, M. 2016. System-focused risk identification and assessment for disaster preparedness: Dynamic threat analysis. European Journal of Operational Research, 254(2), pp. 550-564.

[13] Pretagostini, R., Gabbrielli, F., Fiaschetti, P., Oliveti, A., Cenci, S., Peritore, D. \& Stabile, D. 2002. Risk management systems for health care and safety development on transplantation: A review and a proposal. Transplantation Proceedings, 42(4), pp. 1014-1016.

[14] Bhamra, R., Dani, S. \& Burnard, K. 2011. Resilience: The concept, a literature review and future directions. International Journal of Production Research, 49(18), pp. 5376-5385.

[15] Burnard, K. \& Bhamra, R. 2011. Organisational resilience: Development of a conceptual framework for organisational responses. International Journal of Production Research, 49(18), pp. 5581-5599. 
[16] Parsons, D. 2010. Organisational resilience. Australian Journal of Emergency Management, 25(2), pp. 1820.

[17] Rogers, P. 2011. Development of resilient Australia: Enhancing the PPRR approach with anticipation, assessment and registration of risks. Australian Journal of Emergency Management, 26(1), p. 54-58.

[18] Cook, C. \& Bakker, K. 2012. Water security: Debating an emerging paradigm. Global Environmental Change, 22, pp. 94-102.

[19] Singh, V. 2017. Challenges in meeting water security and resilience. Water International, 42(4), pp. 349359.

[20] Yiannou, A. 2018. Water conservation and recycling in healthcare facilities. Hospital Technical Memorandum No 63. Western Cape Government: Health.

[21] Coetzee, G.P. \& Lubbe, D. 2013. The risk maturity of South African private and public sector organisations. Southern African Journal of Accountability and Auditing Research, 14(1), p. 4556.

[22] The Department of National Treasury of South Africa. 2018. Risk management framework. [ebook] Available at: https://oag.treasury.gov.za/RMF/Pages/s101ExecutiveSummary.aspx [Accessed on 28th April 2018].

[23] Gray, J. \& Thompson, K.C. (eds). 2009. Water contamination emergencies: Collective responsibility. Cambridge, UK: RSC Publishing.

[24] International Organization for Standardization. 2012. ISO 22301:2012 Societal security business continuity management systems requirements. [Online] Available at: https//www.iso.org/standard/50038.html [Accessed on 3rd September 2018].

[25] Business Queensland. 2018. Business continuity planning. [Online] Available at: https: //www.business.qld.gov.au/running-business/protecting-business/risk-management/continuityplanning [Accessed on 3rd September 2018].

[26] Western Cape Government: Health. 2017. New standard of care for surgical hand preparation using alcohol based hand rub. Water Supply Preparedness Plan.

[27] Center for Disease Control and Prevention (CDCP) and American Water Works Association (AWWA). 2012. Emergency water supply planning guide for hospitals and health care facilities. Atlanta, GA: US Department of Health and Human Services.

[28] Environmental Protection Agency (EPA). 2012. Saving water in hospitals. WaterSense. Available from: https: / /www.epa.gov/sites/production/files/2017-01/documents/ws-commercial-factsheet-hospitals.pdf [Accessed on 27 August 2019] 